\title{
An integrated system for tourism destination management: reflections and proposal of a conceptual model from the perspective of hospitality
}

\author{
Aristides Faria Lopes dos Santos ${ }^{\mathrm{a}}$
}

\section{RESUMO}

This report presents the experience of the implementation of the "Tourism Observatory | SIGESTur" project, an action developed at the Federal Institute of São Paulo (IFSP Campus Cubatão). The project began in 2016, as result of academic research and university extension activity. This work reports and analyzes the results of the project, and proposes a model for innovative management of tourism destinations in the Brazilian context. In its first year, the project was considered one of the ten most innovative ideas in Brazilian tourism, at the I Tourism Innovation Camp, a contest promoted by the Panrotas portal with technical support from Sebrae (national development agency). In 2017, the case entitled "Hospitality and hostility relations among stakeholders: Influences in the competitiveness of tourist destinations" received an award during the IV World Research Summit for Tourism and Hospitality, a congress held in Orlando (USA). The project consists of two work fronts. For the elaboration of this report of experience, bibliographical and documentary research were carried out. The data analysis was done in 2019 to ensure that all previous actions were recorded. In the results, the establishment of a model is highlighted, for collecting, processing and analyzing data and distributing information to professionals in the travel and tourism industry.

\section{PALAVRAS-ChAVE}

Tourism

Hospitality

Competitiveness

Innovation

Stakeholders 


\section{INTRODUÇÃO}

This report presents the experience of the Tourism Observatory | SIGESTur, a project developed at the Federal Institute of São Paulo (IFSP Campus Cubatão) through academic research and university extension projects. These actions were carried out as part of the IFSP Programa Institucional de Bolsas de Iniciação Científica [Institutional Program for Research Scholarships], the Programa Institucional Voluntário de Iniciação Científica e/ou Tecnológica [Voluntary Institutional Program for Scientific and/or Technological Research], and the Programa Institucional de Apoio a Ações de Extensão [Institutional Support Program for Extension Actions] of this institution (Notice 823, of November 29, 2016) and the Edital de Fluxo Contínuo PROEXC/SIEX 2017 [PROExC/SIEX 2017 Continuous Flow Public Notice) (Protocol SIGProj: 263667.1362.250286.14032017).

The area of coverage adopted is the Baixada Santista Metropolitan Region (RMBS), where it is headquartered at IFSP Câmpus Cubatão. The courses offered by this unit include, among others, the Events Management Technician Integrated with High School, the Higher Diploma in Tourism Management, and the Bachelor Degree in Tourism.

An important aspect in the choice of this region as a laboratory is the existence of an institutional arrangement related to the travel and tourism sector, which is the focus of the proposal. It includes the following institutions: Sebrae-SP, Costa da Mata Atlântica Convention \& Visitors Bureau, Baixada Santista Metropolitan Agency, The Union of Hotels, Restaurants, Bars and Similar in Baixada Santista and Vale do Ribeira, and the Union of Workers in the Hotel Business, Bars, Restaurants and Similar in Santos, Baixada Santista, South Coast, and Vale do Ribeira. In summary, the main goal of the Tourism Observatory | SIGESTur is to structure a system for collecting, processing, and analyzing data and distributing information to professionals working in the travel and tourism sector. The specific goals of the project are: to complement the inventory of equipment, services and tourism infrastructure of the municipality; to support the elaboration and future revisions of the
Municipal Tourism Master Plan; and stimulate the development of a system for collecting, analyzing and distributing data and information on the regional tourism market.

In the 2017, the case entitled "Hospitality and hostility relations among stakeholders: Influences in the competitiveness of tourist destinations" received an award at the "IV World Research Summit for Tourism and Hospitality", conference held in Orlando (USA).

In recognition of the efforts made for the sustainable development of tourism in Cubatão (SP), the City Council paid tribute to the proponent during a solemn act in September 2018.

From January 2019, the applicant began to take part in the weekly program "Em Cima da Hora" of the online community radio "Rádio da Vila" (http:// www.radiodavila.minharadio.fm/), located in Santos, in the district of Vila Mathias. During the program, topics related to the tourism economy are discussed in a language that is accessible to the general public, seeking to make the local and regional populations aware of the economic, social and even cultural importance of tourism.

The operationalization of the Tourism Observatory | SIGESTur took place through undergraduate research and university extension projects, giving scholarship students linked to the projects listed below an opportunity to carry out their curricular and extracurricular internships.

The projects below underpinned the implementation of the Tourism Observatory | SIGESTur. It is also important to mention that these are being deepened and improved, as part of a doctoral thesis currently underway.

Component projects of the Tourism Observatory | SIGESTur:

- "Competitiveness in the travel and tourism sector: multiple case study in São Paulo coast" (2016);

- "Integrated Tourism Destination Management System" (2016);

- "Entrepreneurship: guidance for tourism business plans" (2017);

- "Observatoriodoturismo.com: monitoring and evaluation of public policies to promote tourism on the São Paulo coast" (2017); 
- "Integrated Tourism Destination Management System: pilot project Cubatão (SP)" (2017).

\section{RESEARCH QUESTION AND RELEVANCE}

Considering, initially, the regional context in which the Tourism Observatory | SIGESTur and the abovementioned satellite projects are being implemented, we see that there are four main demands to be met:

- Integration between stakeholders in the travel and tourism sector; creation and dissemination of content on the performance of the tourism market and public policies to promote tourism;

- Historical data on the performance of tourism businesses in relation to the local, regional, state, national and international economic contexts; and

- Institutionalization of actions to support the management of the tourism destination - in this case, the pilot actions take place in the "Costa da Mata Atlântica", the name given for tourism purposes, to the Baixada Santista Metropolitan Region on the coast of the state of São Paulo, which comprises the municipalities of Bertioga, Cubatão, Guarujá, Itanhaém, Mongaguá, Peruíbe, Praia Grande, Santos and São Vicente.

\section{THEORETICAL FRAMEWORK}

\section{Relations of hospitality and hostility relations in the context of public management of tourism}

It is considered important to present some reflections, albeit initial, on the relations of hospitality and hostility in the context of public management of tourism. This means that when proposing this "conceptual model", we seek to guide the vision of managers of public and private organizations, based a different perspective from the usual one.

The proposal for the Tourism Observatory arose out of discussions on the relations of hospitality relations, and on its opposite side, hostility. The theoretical framework adopted is composed of authors and works from different countries and research institutions, in order to achieve different views on the relations between public authorities and their multiple stakeholders.
In a study that addresses the ambivalence of hospitality in public spaces, Wassall \& Salles (2019) point out two essential aspects: exclusion and the possibility of conflicts. These factors can also be discussed in the organizational context. The hospitality-hostility duality emerges in different contexts, as discussed in the texts presented below.

In an article dedicated to discussing the challenges around education for hospitality service management, Lugosi \& Jameson (2017) present a broad index of qualitative data on UK-based educators, in order to examine their perceptions of their professional performance in contemporary times. Initially, the following factors were proposed: engagement of students, especially through the adoption of new technologies (1); the growth in the number of foreign students (2); institutional restrictions, pressure for resources and the distinction of education for hospitality management (3); tensions between intellectual development in the field of hospitality and the different possible focuses in its practice (4); and new designs, content, models for the operation of courses and partnership formats (5) - this latter topic/ challenge also includes distance education.

Among the main results it was found, through the interviews, that the commercialization of higher education, the globalized nature of competitiveness at undergraduate and graduate levels, and changes in the financing formats of higher education institutions have forced these organizations to review their business models and the design of their hospitality courses - including courses in tourism, gastronomy, hospitality and events management. The data found reflect the factors proposed a priori, and indicate the importance of educational practices that seek to effectively integrate the business (market) and the academic world.

According to Lashley (2015), there are several possible reasons for offering hospitality, but the natural characteristics of those who are genuinely hospitable is a matter of great relevance in studies on hospitality in all its domains - sociocultural, private and commercial (Lashley, 2000; 2008). 
Cockburn-Wootten \& Brewis (2014) sought to discuss hospitality in the organizational context, analyzing the "hospitality spaces" generated from the professional practice of social service. It is interesting to note that a significant part of the work in this area occurs inside the homes of those who can be identified as beneficiaries. Hence the correlation, mentioned in the title of that article, with the doorstep, i.e. the professional's access to the private space of people in the community.

The authors point out that the commercial domain of hospitality is prevalent, and has been adopted by teachers in the area of management, as a management tool. Thus, the study adopts the threefold concepts of "organizations", "occupations" (jobs, in this case, in social service) and "spaces", in its conceptualization and contextualization of hospitality in the sociocultural context.

The results of that work show that social service professionals developed asymmetrical relationships of trust, which led to the consolidation of hospitality spaces. The results also showed that social service is exercised at the thresholds between organizations and society. Indeed, the role of the one providing the social service has been impregnated with the notion of hospitality, as it does not require the establishment of relationships based on trust and social inclusion (altruism?) of individuals who, for whatever reason, have been or are excluded from society.

Another important author that is part of the theoretical framework of this work is Theorga (2016), who analyzes the performance of several tourist observatories that exist in contemporary Brazil. Among the "observatories established", those based in Belo Horizonte (MG), Brasília (DF), Goiânia (GO), Salvador (BA), São Paulo (SP) and Vitória (ES) were objects of investigation.

The theoretical basis of the Tourism Observatory | SIGESTur originates, then, in experiences such as those investigated by Theorga (2016), and the critical success factors for destination management systems (DMSs) advocated by Buhalis \& Deimezi (2004, p. 126), which are listed below:

- Vision, commitment and strategic understanding at the top;
- Complete and comprehensive representation of the entire range of tourism enterprises and services;

- Accurate information, tourism product pricing and impartial showcasing of offers (randomized, for example);

- Guaranteed of confirmed bookings;

- Strong political and industrial support;

- Secure and adequate financial base, based on a realistic business model;

- Interconnectivity and interoperability of systems;

- Multichannel strategies, capitalizing on all technologies;

- Strong links with all distribution partners and mechanisms;

- Technology must always follow business models, not necessarily lead them;

- Large number of added value services, based on personalized information;

- Micro-sites for niche markets and specialized groups;

- Convenient payment methods for consumers, payment of commission for all intermediaries involved in a booking, and prompt settlement with suppliers;

- Easy, clear and accessible interfaces;

- A degree of standardization between DMSs;

- Marketing of DMS both to consumers and to the online and offline travel trade;

- SMTEs should be involved at an early stage and should be autonomous.

Wang \& Xiang (2007) propose key variables for destination marketing management, based on a structured model with four constructs: preconditions for the formation of market alliances, motivation for entering into market alliances, the formative process of market alliances, and stratification of the results (outputs).

From there, breaking down the diagram presented by the authors, thirty-one variables were identified within the group of processes, the focus of this study. Thus, in Table 1, in the results section, the conceptual model of the Tourism Observatory is presented | SIGESTur through the approximation between functionalities of a technology-based solution and the key variables recommended by Wang \& Xiang (2007). 


\section{METODOLOGY}

We see that the Tourism Observatory | SIGESTur consists of two work fronts. The first is focused on data collection, processing, and analysis and the second is dedicated to the distribution of information to professionals working in the travel and tourism sector.

The actions of this first work front are performed regularly by the proponent and the work team, which is made up of scholarship students, as explained above. The work of distributing information i.e. the data analyzed and transformed into language that is accessible to the general public - is done by the proponent.

As explained, the structuring of the Tourism Observatory | SIGESTur over time took place through academic research and university extension projects, which were directly related to the teaching activity of the proponent. The scholarship students who took part in these projects were responsible for assisting in the elaboration and validation of the data collection instruments, the research into sources and references, the elaboration of communication material, and the writing of partial and final reports.

These tasks were carried out through remote work and at the facilities of the IFSP Campus Cubatão Tourism Laboratory, where weekly orientation meetings were held throughout 2016 and 2017.

From September 2017, the proponent obtained leave to pursue a qualification (doctorate degree), starting the operationalization of the Tourism Observatory | SIGESTur itself, since the project is part of the doctorate thesis currently underway, the deadline for completion being December of this year.

The analyzed data is disseminate through a blog that is managed by the proponent. The page can be accessed at www.sigestur.com. This blog publishes content from the analysis of data collected from companies and official sources.

More specifically, a prototype of the "Integrated Destination Management System" was developed in the form of a mobile app that is available for free download from http://app.vc/sigestur. The app is a model that can be adopted by tourism destinations, and also acts as a channel for the distribution of information from data analyses developed within the Tourism Ob- servatory | SIGESTur.

The SIGESTur app has a global positioning system (GPS), a screen with general information about the municipalities, and a regional calendar of events. Besides these tabs, there are also tables that show information about services, attractions and tourism facilities. Another section in operation addresses transparency in the management of public resources. This is a space where destination managers can provide users with open data on investments and expenses in the management of the tourism destination - in the execution of works or contracting of services by the municipal government, for example.

This solution has a low implementation cost and can be adapted to the reality of each Brazilian tourism destination - always safeguarding the premise of integration, as advocated by Eichhorn, Miller, Michopoulou \& Buhalis (2008).

The authors state that " (...) it is important that the focus be on an integrated system that is less discriminatory, that tends to increase the relevance of an inclusive tourism model without barriers in society, and that provides access to detailed information on available conveniences and specific means for access/consumption "(Eichhorn et al, 2008).

In addition to the strategies and actions for disseminating information about the project, another important aspect to mention is the weekly participations of the proponent in the program "Em Cima da Hora", of the online community radio "Rádio da Vila" (http:// www.radiodavila.minharadio.fm/) located in Santos, in the district of Vila Mathias.

The program airs every Thursday between 8 am and 9 am, but remains online on the YouTube platform. This action is carried out by the proponent, who was the coordinator of the abovementioned undergraduate and undergraduate academic research and university extension projects. The aim of the initiative is to bring a useful service to a wider public, commenting, in accessible language, on the impacts of tourism on the regional economy.

Based on the theoretical framework adopted, and the experience of implementing the Tourism Observatory | SIGESTur, it is clear that government action at municipal level can directly influence the competitiveness of 
the travel and tourism sector in each tourism destination.

The project in question is organic and, of course, is under constant review as it is an integral and inseparable part of the Doctorate in Hospitality prepared by the proponent of the Anhembi Morumbi University School of Tourism and Hospitality (Laureate International Universities), a traditional and important tourism research center in Brazil.

The results of the project as a whole are, for now, immaterial and required few financial resources. The biggest costs to date have been the scholarships awarded to students of the above projects.

Data mining from official sources, such as public transparency portals and open access data, is the main strategy for cutting the costs of data collection. This means using official sources, processing the data collected, analyzing them in light of the travel and tourism industry, and promoting the dissemination of these analyses through low cost channels.

Disruptive communication is, in this sense, a hallmark of the Tourism Observatory | SIGESTur, because all users of the worldwide computer network who are interested in the performance of the travel and tourism market in a given location can quickly and freely access reliable information that has been technically analyzed by specialized professionals - scholarship students and teachers of the Federal Network of Vocational, Scientific and Technological Education Institutions.

Thus, the public utility of this project is configured. Undoubtedly, the project has achieved its purpose of raising awareness of the local host community, i.e. the community that welcomes the tourist and receives the positive and negative impacts of tourism activity, as to the economic, social and cultural importance of tourism.

It is important to highlight that the proposed management model, developed within the scope of indirect public administration at federal level, considers the Brazilian socio-cultural breadth and complexity. Given the low cost, the use of official data sources, the free access and replication of this model, and the possibility of consultation through the establishment of institutional agreements, this initiative proves to be viable and in keeping with the precepts of Community tourism.

Some examples of this conceptual model of sustainable tourism are visits to traditional communities, historical villages, localities that were once quilombolas (former slave settlements), indigenous settlements, or villages outside the conventional mass tourism itineraries.

Finally, by popularizing access to and understanding of the impacts of tourism on society, the proposed tourism destination management model advocates the empowerment of host communities, which can promote social equity, racial and gender equality, and inclusion in the job market.

\section{RESULTS}

The establishment of a tourism destination management model is proposed, based on the premise that each destination has its own characteristics in terms of its institutional arrangement, management resources and administrative capacity.

Considering such peculiarities, the Tourism Observatory | SIGESTur was conceived, as described above, with two fronts of action. A possible development of the project is the creation of a mobile app prototype, as a model that can be adopted by tourism destinations and also act as a channel for disseminating information from the data analysis developed within the Tourism Observatory | SIGESTur. The characteristics of "replicability" and "self-management" are considered applicable to describe the project.

Given that the Tourism Observatory | SIGESTur was originally developed through the integration of undergraduate and undergraduate projects, the evaluation process (or processes) were conducted on a regular basis. Also, the successful dissemination effort involves regular submission of the project for evaluation by conferences and periodicals.

The innovative aspect of the information dissemination phase is that it provides simple, efficient and transparent access to information in a user-friendly, visual, accessible and accurate way.

The conceptual basis of the project consists of studies on hospitality, competitiveness and sustainability, and it is the articulation of these themes that provides the 
innovative character of the Tourism Observatory | SI-

GESTur.

Table 1: Conceptual model of a technology-based solution for the management of tourism destinations in light of the variables of Wang \& Xiang (2007).

\begin{tabular}{|c|c|}
\hline Functionality & Objective \\
\hline Destination & $\begin{array}{l}\text { Gather institutional information on municipalities in the region (or neighborhoods in the city } \\
\text { and states of a country, for example) and geographical data deemed to be of technical and } \\
\text { administrative interest. }\end{array}$ \\
\hline Events calendar & $\begin{array}{c}\text { Give information about trade events held or supported by the government, both in public and } \\
\text { private spaces. This is not advertising or commercial information, but technical data, business } \\
\text { opportunities and commercial contacts. }\end{array}$ \\
\hline GPS (map) & Assist in travel to and identification of the location of attractions or tourist services. \\
\hline Blog & $\begin{array}{l}\text { Publicize diverse content about the tourism destination. The page may contain a range of } \\
\text { contents, such as articles, images, itineraries, comments and reviews, useful links, public ser- } \\
\text { vices, and other content of public interest. }\end{array}$ \\
\hline Podcast & $\begin{array}{l}\text { Produce content aimed by corporate audiences, sharing interviews, reviews, market and sector } \\
\text { analysis and debate programs on the travel and tourism sector, for example. }\end{array}$ \\
\hline Fan page & Share news and information of public interest about the destination. \\
\hline Twitter & Share news and information of public interest about the destination. \\
\hline Business network & $\begin{array}{l}\text { Promote communication between stakeholders, establishing partnerships and strategic alli- } \\
\text { ances. This functionality has a strong integration characteristic, which is the essential premise } \\
\text { of SIGESTur. In this tab, for example, sector entities and their associates can be registered so } \\
\text { that they have access to broader and inter-sector business networks. The club format is sug- } \\
\text { gested, which includes invited participants. }\end{array}$ \\
\hline Business opportunities & $\begin{array}{l}\text { Establish an archive of supply and demand for opportunities, both for services and available } \\
\text { labor. This will enable businesses to offer services and products to the trade, as well as other } \\
\text { professionals, and to offer proposals and make offers. Through the network created at the } \\
\text { destination, consortium purchases can be made, for example, with major suppliers for the } \\
\text { hospitality industry. }\end{array}$ \\
\hline $\begin{array}{l}\text { Observatory } \\
\text { (data on the sector) }\end{array}$ & $\begin{array}{l}\text { Collect, process, analyze data and distribute information. These are the functions of the tour- } \\
\text { ism observatory, together with the distribution or dissemination of content to members of a } \\
\text { given network or community in an assertive and effective way. }\end{array}$ \\
\hline Public investments & $\begin{array}{l}\text { In this tab, public investments that have been executed, or are in progress and/or pending, } \\
\text { and are funded by tourist portfolios and the like, can be registered. The addition of data on } \\
\text { the management of the local fund could also be considered. }\end{array}$ \\
\hline Meetings of COMTUR & $\begin{array}{l}\text { Provide a calendar, notices, invitations, public calls, agendas, and minutes of meetings. The } \\
\text { identification, mapping, classification, and integration of stakeholders involves managing their } \\
\text { demands, which is expected of the Council. }\end{array}$ \\
\hline
\end{tabular}


As we have seen, the proposal of a conceptual model for the management of tourism destinations in the Brazilian context requires theoretical and market references. This means that the search for innovative models or concepts requires ongoing research on (possible) solutions from around the world, both for the management of tourism activity directly and for its management in relation to other sectors of the economy.

Although still in the preliminary stages, and still under construction, it is believed that this work can serve as a reference for companies, third sector organizations and public bodies, when structuring their processes and systems (physical and computational), as described in the following section.

\section{PRACTICAL IMPLICATIONS AND CONCLUSIONS}

It should be mentioned that the implementation of the Tourism Observatory | SIGESTur through academic projects, linked to IFSP Campus Cubatão, with the participation of scholarship students, requires the preparation of projects and partial reports of those projects, which are submitted at the end of the first semester, and final reports, which are presented at the end of each year, when the projects are completed.

The repercussions of the project can be seen as an evaluation metric, i.e., the disclosure of the actions inherent to the Tourism Observatory | SIGESTur by non -tourism media outlets means that one of the aims of the project has been achieved, which was to raise awareness of the local community regarding the economic, social and cultural benefits of tourism.

Another relevant aspect is the adherence to and/or support for the project by the municipalities of the Baixada Santista Metropolitan Region. In 2016, the then Secretary of Tourism of the city of Cubatão (SP) signed a letter of support to implement a pilot project in that city. Another important record refers to the note published in the newspaper Diário do Litoral, entitled "Guarujá terá Observatório de Turismo" (Guarujá to get a Tourism Observatory) (https:// www.diariodolitoral.com.br/cotidiano/guaruja-teraobservatorio-de-turismo/113703/), which reported on an agreement set up to organize and disseminate information on the performance of the municipality in the regional tourism market.

Throughout the various phases of implementation of the Tourism Observatory | SIGESTur, which comprised academic research and university extension project, goals were established, such as the elaboration and publication of the SIGESTur app, the registration of the domains < www.observatoriodoturismo.com > and $<$ www.sigestur.com $>$ and the collection, analysis and distribution of data on the performance of the region's tourist attractions, the legal environment of the sector in the state of São Paulo, and the institutional arrangements inherent to the travel and tourism sector.

These goals were achieved, contributing to the consolidation of the project to date. The culmination of all this effort will occur at the end of this year, as the project has a doctoral thesis currently underway. Once that is completed, an manual should be published on the implementation of a tourism destination management system, for example.

Throughout the history of the project, in order to obtain validation of the proposed conceptual model by the market, the Tourism Observatory | SIGESTur was presented, at a meeting of the Sustainable for Studies on Sustainable Tourism (ABNT-CE 54.0004.01) of the Brazilian Association of Technical Standards, which is part of the Brazilian Tourism Committee of this institution (ABNT/CB-054).

Another potential outcome of the proposed destination management model is the formulation of a technical standard to guide the management of sustainability and competitiveness of Brazilian tourism destinations, which motivated this joint action with the ABNT.

\section{REFERÊNCIAS}

Buhalis, D. (2000). Marketing the competitive destination of the future. Tourism Management, 21(1), 97-116.

Cockburn-Wootten, C.; Brewis, J. (2014). Crossing thresholds: Hospitality and professionalism in Aotearoa New Zealand social work. Hospitality \& Society, 4(2), 115-133.

Eichhorn, V.; Miller, G.; Michopoulou, E.; Buhalis, D. (2008). Enabling access to tourism through information schemes? 
Annals of Tourism Research, 35(1), 189-210.

Lashley, C. (2015). Hospitalidade e hospitabilidade. Revista Hospitalidade, 12, 70-92.

Lashley, C. (2008). Studying Hospitality: Insights from Social Sciences1. Scandinavian Journal of Hospitality and Tourism, 8(1), 69-84.

Lashley, C. (2000). Toward a theoretical understanding. In: Lashley, C.; Morrison, A. (Eds.) In Search of Hospitality: Theoretical Perspectives and Debates. Oxford (UK): Butterworth-Heinemann.

Lugosi, P.; Jameson, S. (2017). Challenges in hospitality management education: Perspectives from the United Kingdom. Journal of Hospitality and Tourism Management, 31, 163172.

Theorga, A. B. (2016). Os Observatórios de Turismo no Brasil. Dissertação (Mestrado em Turismo)- Universidade de Brasília, Brasília.

Wang, Y.; Xiang, Z. (2007). Toward a Theoretical Framework of Collaborative Destination Marketing. Journal of Travel Research, 46(1), 75-85.

Wassall, A. R. A.; Salles, M. R. R. (2019). Cidades e praças: ambivalência da hospitalidade em espaços públicos. Revista Rosa dos Ventos, 11(2), 386-399. 